\title{
Changes in the ichthyofauna of an artificial reef in the southeastern Mediterranean in one decade*
}

\author{
E. SPANIER \\ The Leon Recanati Institute for Maritime Studies and Department of Maritime Civilizations, University of Haifa, Mount \\ Carmel, Haifa 31905, Israel. Telephone: 972-4-8240782, 972-4-8240600; Facsimile: 972-4-8240493. \\ E-mail: spanier@research.haifa.ac.il
}

\begin{abstract}
SUMMARY: Species composition and numbers of bony fish were studied in a small artificial reef complex off the northern Mediterranean coast of Israel. On this site visual censuses of fish carried out by SCUBA divers once a month over a twelve month period in 1985-6 and again in 1995 showed that only one species of fish and one species of macro-invertebrate were added in 1995 to a total of 36 species of fish and four macro-invertebrates counted ten years earlier. Of the fish species recorded on the artificial reef $18.7 \%$ were Lessepsian migrants from the Red Sea, passing to the eastern Mediterranean through the Suez canal; $75.7 \%$ were of Atlanto-Mediterranean origin. The contribution of Red Sea species to the overall fish biomass in the artificial reef complex however, increased from 64\% in 1985-6 to 94\% in 1995. The change was due mainly to a significant increase (244\%) in the population of the Red Squirrelfish Sargocentron rubrum and a decrease in the population of sparids (41-90\%) and Dusky Grouper, Epinephelus marginatus (44.8\%). Similar increases in Red Sea immigrants were reported by coastal fisheries and observed in other artificial and natural outcrops. One possible explanation for this phenomenon is the competitive exclusion of autochtonous species by a successful Lessepsian migrant, taking over spatial and perhaps food resources. Over-fishing of the commercially important groupers and sparids may provide an alternative explanation for this biomass change in the ichthyofauna. In view of these findings, artificial reefs are suggested as representative sites for observations on long-term ecological changes in bony fish populations.
\end{abstract}

Key words: Species composition, fish abundance, artificial reefs, Continental shelf, southeastern Mediterranean, Red Sea migrants.

\section{INTRODUCTION}

Thousands of artificial reefs have been constructed around the world since their effectiveness in the enhancement of fisheries was revealed by the Japanese in the late 18th century (Stone et al., 1991). Most artificial reef studies have, however, overlooked biogeographical changes. With respect to finfish, ecological questions addressed were associated with the rate of recruitment of autochtonous fishes and interactions among them, such as competition and

\footnotetext{
*Received August 10, 1998. Accepted January 21, 2000.
}

predation (e.g., Bohnsack et al., 1991, Bortone et al., 1994; Santos et al., 1997). Due to technological developments and large-scale engineering projects, however, there are certain marine regions where man has induced considerable biogeographical changes, as reflected in the marine biota. One of the best examples of such a process is the Levant basin in the southeastern Mediterranean. The opening of the Suez Canal in 1869 initiated a significant event, the joining of two biogeographical provinces, the Red Sea and the Mediterranean. Since 1869, over 200 Red Sea species have been recorded in the Eastern Mediterranean, including 55 species of bony 
fishes (Golani, 1996), within a total of 636 bony fish species recorded in the Mediterranean (Fredj and Maurin, 1987) and 410 species known in the eastern Levant basin (Golani, 1996). These Red Sea migrants managed to cross the canal and penetrate the Mediterranean in a process termed "Lessepsian migration" (after Ferdinand Marie de Lesseps, the French diplomat and engineer who built the canal) (Por, 1978, 1989). The process of Lessepsian migration is a dynamic one and still continues (Por, 1989; Spanier and Galil, 1991).

How do these continuous biogeographical changes affect the species composition and biomass of bony fish recruited to artificial reefs? Ecological changes occur over space and time. It is not unusual that these changes are detectable only after a relatively long time scale, in an order of magnitude of many years. Can changes of this nature be detected in an artificial reef over a decade? This aspect was investigated in an experimental artificial reef complex off the Mediterranean coast of northern Israel.

\section{MATERIALS AND METHODS}

A small artificial reef complex made of car tyres was used in this study. Tyres were chosen due to their low cost, durability and open structure, that are advantages in the construction of marine habitats for fish and macro invertebrates. Four artificial reef units were constructed from used car tyres of $32 \mathrm{~cm}$ inner diameter, $65 \mathrm{~cm}$ outer diameter and $17 \mathrm{~cm}$ width, connected by $18 \mathrm{~mm}$ thick steel bars and weighted with concrete poured into the bottom part of the lowest layer of tyres. The units were designed in various configurations (horizontal, vertical and mixed) to assess the differential recruitment of the various species to different structural components of the reefs. The reef units were deployed in fall 1983 at a depth of $18.5 \mathrm{~m}, 1,700 \mathrm{~m}$ southwest of the Israel National Institute of Oceanography, Tel-Shiqmona, Haifa, Israel ( $\left.32^{\circ} 50^{\prime} \mathrm{N}, 34^{\circ} 56^{\prime}\right)$. The placement site was a flat area on the sea bed consisting of low biogenic rocks (not higher than $20 \mathrm{~cm}$ ) and coarse sand, [for additional details on these reef units, and differential recruitment of fish and macro-invertebrates to the reefs' components see Spanier (1989, 1997), Spanier et al., (1985a, 1985b, 1988, 1989, 1990)]. Before the deployment of the reefs, fishes were sampled monthly using trammel nets. This sampling was done on a natural low coralligeneous substrate at a similar depth and in the general area of the arti-

ficial reefs (Spanier et al., 1989). A visual census of bony fish was made during daylight (Russell et al., 1978). The censuses were carried out once a month via SCUBA diving by a team of four experienced biologists familiar with the ichthyofauna of the reef. Each census lasted 50 minutes (maximum nondecompression bottom time at this depth). Two divers covered each reef unit and their data were compared and averaged to yield the final result for each reef unit per census. Censuses were done dur-

TABLE 1. - Species of bony fish and macro-invertebrates found in the artificial reef complex during 1985-6 census and those added during 1995 censuses *. Common and Latin names of fishes are according to Lythgoe and Lythgoe (1992) and Whitehead et al. (1984, 1986a, 1986b), while those of invertebrates are according to Campbell (1982). Origins: A, Atlanto-Mediterranean; C, cosmopolitan; R, Red Sea.

Species Common name Origin

Fishes

Apogon imberbis $\mathrm{L}$.

Alepes djeddaba (Fosskal)*

Balistes carolinensis Gmelin

Blennius ocellaris L.

Boops boops L.

Chromis chromis L.

Coris julis L.

Diplodus cervinus (Lowe)

D. sargus L.

D. vulgaris (G. Saint Hilaire)

Epinephelus aeneus (G. Saint Hilaire)

E. alexandrinus Valenciennes

E. marginatus (Lowe)

Gobius sp.

Lithognathus mormyrus L.

Maena (spicara) smaris L.

Mullus surmuletus L.

Muraena helena L.

Oblada melanura L.

Pagrus coeruleostictus Valenciennes

Pempheris vanicolensis Cuvier

Sardinella aurita Valenciennes

Sargocentron rubrum (Forsskål)

Sparisoma cretense $\mathrm{L}$

Sciaena umbra L.

Scorpaena porcus L.

S. scrofa L.

Seriola dumerilli (Risso)

Serranus cabrilla L.

S. scriba L.

Siganus luridus (Rüppell)

S. rivulatus (Forsskål)

Sphyraena chrysotaenia Klunzinger

Stephanolepis diaspros Fraser-Brunner

Symphodus mediterraneus L.

S. tinca $\mathrm{L}$.

Thalassoma pavo $\mathrm{L}$.

Bivalves

Glycymeris pilosus L.

Pinctada radiata (Leach)*

Venus verrucosa L.

Cephalopods

Octopus vulgaris (Lamarck)

Crustaceans

Scyllarides latus (Latreille)
Cardinal Fish

Shrimp's Scad

Mediterranean Trigger Fish

Butterfly Blenny A

Bouge

Mediterranean Damsel Fish A

Rainbow Wrasse A

Zebra Sea Bream A

White Sea Bream A

Tow-banded Bream A

White Grouper

Golden Grouper

Dusky Grouper

Goby

Marmora

Picarel

Red Mullet

Mediterranean Moray Eel

Saddled Bream

Blue Spotted Sea Bream

Vanikoro Sweeper

Gilt Sardine

Red Squirrel Fish

Parrot Fish

Brown Meagre

Brown Scorpion Fish

Red Scorpion Fish

Amberjack

Comber

Painted Comber

Rabbit Fish

Rabbit Fish

Yellow Tail Barracuda

Filefish

Axillary Wrasse

Painted Wrasse

Rainbow Wrasse

Cockle Shell

Little Pearl Oyster

Warty Venus

Common Octopus

A 
ing the day-time between $0900 \mathrm{hrs}$ and $1500 \mathrm{hrs}$ over twelve months from March 1985-February 1986, and once again using the same methods and the same team over twelve months from January December 1995. Data were recorded in situ on polyvinyl chloride boards. Holes and crevices were inspected using underwater flashlights. Supplementary information was obtained by underwater photography (Nikonus V). No artificial enrichment ("chumming") similar to that done by Spanier et al., (1985a) was done during these periods. Fishes were identified and their sizes (TL) were estimated visually and recorded underwater. Species identification was based on Whitehead et al. (1984, 1986a, 1986b) and Lythgoe and Lythgoe (1992). Biomass estimations were obtained by multiplying the average weight of a given species in a given size range, by the number of fish of this species censused in this size range in the reef. Information regarding weight was derived from the trammel net sampling, as well as from commercial fishing in the same region.

\section{RESULTS}

The list of species of fish and macro-invertebrates observed on the artificial reef complex during the 1985-86 and 1995 censuses is presented in Table 1. Thirty-six species of bony fishes and four macroinvertebrates were counted in the artificial reefs in 1985-86. Thirty-seven species of bony fishes and five macro-invertebrates were observed in 1995.

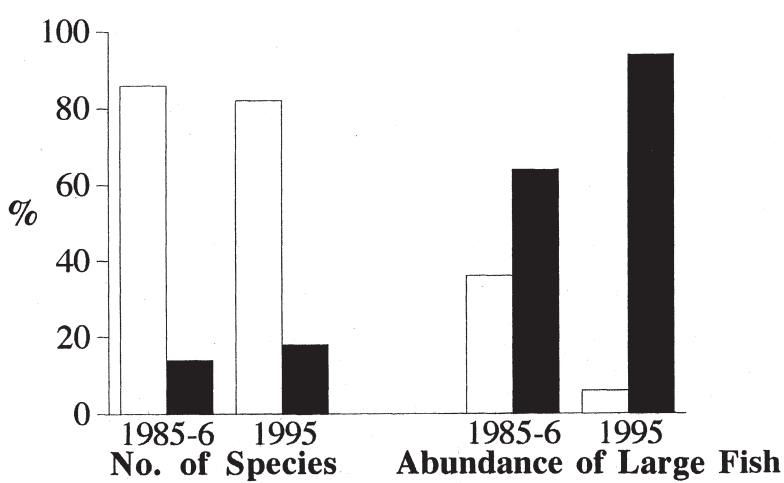

FIG. 1. - The contribution of Atlanto-Mediterranean (white) and Red Sea (black) species to species richness (\% of the total number of species observed) (left) and abundance (\% of total number of individuals) of large fish (right) in the artificial reef complex.

The majority of species recorded on the artificial reef are of Atlanto-Mediterranean origin (Fig. 1) and this ratio changed minimally in the last ten years by the addition of only one Lessepsian fish species. Most of the fish biomass was contributed, however, by relatively large fish (T.L. $>15 \mathrm{~cm}$ ) belonging to 8 autochtonous and Lessepsian species common in the man-made reefs (Table 2). Although the average sizes of large fishes did not change considerably in the decade, a substantial increase in the contribution of Red Sea fishes to the biomass of the reefs was detected (Fig. 1). This increase was also reflected in the percentage of the estimated biomass (Table 2). According to these estimations, the contribution of Red Sea migrant species has increased from an aver-

TABLE 2. - A comparison between the total number of individuals per species of large fish (T.L. $>15 \mathrm{~cm})$ found in the artificial reefs during 1985-86 and 1995 and the corresponding estimated biomass. The average weight of 'large' fish is based on data from trammel net yields and other fishery data (according to Spanier et al., 1989)

\begin{tabular}{|c|c|c|c|c|c|}
\hline Species & $\begin{array}{c}\text { Total \# of } \\
\text { individuals } \\
1985-86\end{array}$ & $\begin{array}{c}\text { Total \# of } \\
\text { individuals } \\
1995\end{array}$ & $\begin{array}{c}\text { Average } \\
\text { weight /fish } \\
\text { (g) }\end{array}$ & $\begin{array}{c}\text { Estimated } \\
\text { biomass }(\mathrm{g}) \\
1985-86\end{array}$ & $\begin{array}{c}\text { Estimated } \\
\text { biomass (g) } \\
1995\end{array}$ \\
\hline \multicolumn{6}{|l|}{ Mediterranean origin } \\
\hline Diplodus sargus & 318 & 32 & $70 \pm 6$ & 22260 & 2240 \\
\hline D. vulgaris & 17 & 10 & $90 \pm 8$ & 1530 & 900 \\
\hline Epinephelus alexandrinus & 8 & 10 & $300 \pm 20$ & 2400 & 3000 \\
\hline E. marginatus & 29 & 16 & $450 \pm 24$ & 13050 & 7200 \\
\hline Pagrus coeruleusticus & 31 & 3 & $100 \pm 11$ & 3100 & 300 \\
\hline Contribution of Mediterranean species & 403 & 71 & & 42340 & 13640 \\
\hline \multicolumn{6}{|l|}{ Red Sea origin } \\
\hline Sargocentron rubrum & 204 & 702 & $110 \pm 7$ & 22440 & 77220 \\
\hline Siganus luridus & 233 & 199 & $50 \pm 4$ & 11650 & 9950 \\
\hline S. rivulatus & 278 & 237 & $35 \pm 6$ & 9730 & 8295 \\
\hline Contribution of Red Sea species & 715 & 1138 & & 43820 & 95465 \\
\hline Total & 1118 & 1209 & & 86160 & 109105 \\
\hline
\end{tabular}




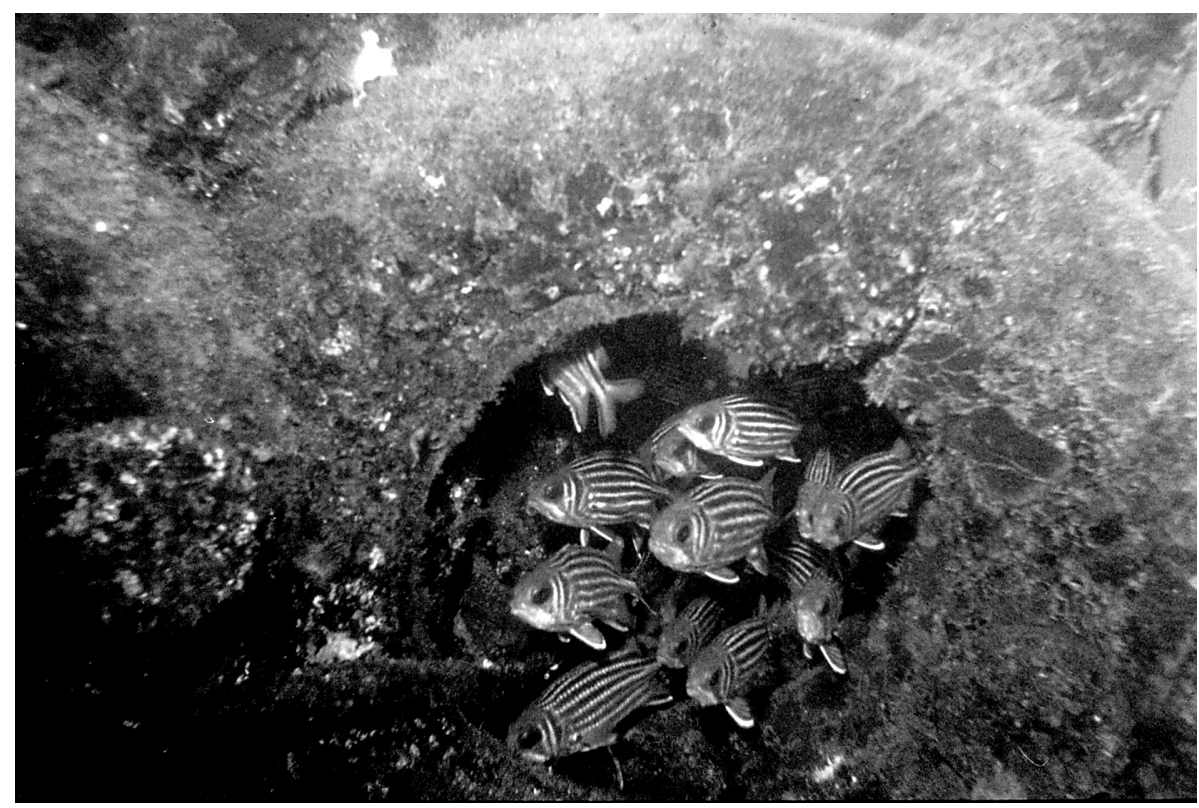

FIG. 2. - Red squirrelfish in the artificial reef complex in the south-eastern Mediterranean (Reduced to $23.4 \%$ of the original size) (Photographed by S. Breitstein).

age of $3.65 \mathrm{~kg}$ per census $(50.9 \%$ of the estimated total biomass of large fish in the reefs) in 1985-86 to an average of $7.96 \mathrm{~kg}$ per census (87.5\%) in 1995. This change is due mainly to the increase in the number of Red Squirrel fish, Sargocentron rubrum (Forsskål) in the artificial reefs (Fig. 2), with a corresponding decrease in the number of indigenous groupers and Mediterranean sparids (Table 2). There was an $8.1 \%$ increase in the total number of large fish (and the total estimated biomass) in the artificial reef complex over the decade (Table 2).

\section{DISCUSSION}

The percentage of Red Sea species in the studied artificial reef ichthyofauna has increased from $16.7 \%$ in $1985-6$ to $18.9 \%$ in 1995 . This is somewhat higher than the relative reported contribution of Lessepsian species to the overall fish species in the Levant basin (13.4\%; Golani, 1996). The most obvious change in the ichthyofauna of the artificial reef complex over the decade is, however, the increase in the contribution of Red Sea species to the overall fish biomass in the man-made complex. In 1985-6 Red Sea species contributed 64\% of the large fish in the artificial reef (compared to $46 \%$ in a natural coralligeneous habitat according to Spanier et al., 1989). Within ten years this contribution has increased to $94 \%$ of the large fish in the reef (Fig. 1), compared to a relatively small increase $(8.1 \%)$ in the total number of fish observed in the reef over time (Table 2). No structural changes took place in the reef units during this decade. Thus, the increase can clearly be attributed to a significant enlargement of the population of the Red Squirrelfish S. rubrum (increase of 244\%) and a decrease in the populations of the sparids (41-90\%) and the Dusky Grouper, Epinephelus marginatus (Lowe) (formerly E. guaza L.) $(44.8 \%)$ (Table 2). There was a small decrease in the number of Rabbitfishes found in the reef over time, of $14.6 \%$ for Siganus luridus (Rüppell) and of $17.3 \%$ for S. rivulatus (Forsskål). These small declines, together with the small increase in the numbers of Golden Grouper, E. alexandrinus Valenciennes (Table 2) may be due to annual or random fluctuations in local abiotic or biotic conditions. The significant increase in the number of Red Squirrelfish (that more than compensated for the small decrease in the number of the Red Sea Rabbitfishes) in conjunction with the decrease in the numbers of sparids and Dusky Groupers, however, may be associated with a more wide-spread phenomenon. This assumption is supported by reports of an increase in the amount of Squirrelfish in fishery yields and a decrease in the catch of sparids and groupers along the Mediterranean coast of Israel (Pisanty, personal communication, 1996), in addition to our observations of other artificial and natural hard bottom habitats off the northern coast of Israel. The present abundance of Squirrelfish caught in trammel nets operating on hard substrates of the shallow conti- 
nental shelf of Israel exceeds the value of $8.7 \%$ reported by Spanier et al. (1989) for the yield using the same fishing equipment. This species is not a target species in the Israeli coastal fishery.

It is possible that we are witnessing a process of competitive exclusion similar to the interrelations between other Lessepsian migrants and Mediterranean species sharing similar ecological niches (Por, 1978, 1989; Spanier and Galil, 1991). S. rubrum is a successful migrant and an ecological generalist even in its feeding habits (Golani et al., 1983). Thus, it is able to compete successfully with the more specialist, autochtonous Mediterranean species. Over-fishing of the commercially important Dusky Groupers, and to a lesser extent of commercial sparids may supply an alternative or additional explanation to this biomass change in the ichthyofauna. The price of E. marginatus in the Israeli market exceeds $\$ 20$ per $\mathrm{kg}$ and fishing pressure on this species is enormous. This highly valued fish is caught not only in nets and long-lines by professional fishermen but also via spear fishing by SCUBA divers. There is a great selection pressure to catch larger groupers. The Squirrelfish, despite being occasionally found in the yield of the Mediterranean coastal fisheries as a by-catch of other commercial species, has no demand in the Israeli market because of its heavy scales.

The Squirrelfish is not occupying "empty ecological niches" in the Mediterranean, at least in regard to habitat. Spanier et al. (1990) studied habitat preference of large bony fishes and macro-invertebrates in the same artificial reef complex as in the present study. They found that in the reef units $73.2 \%$ of S. rubrum were found in the bottom part of the reef (up to $90 \mathrm{~cm}$ above the bottom), as well as $88.5 \%$ of the sedentary E. marginatus and $62.7 \%$ of Diplodus sargus. These habitat preferences are also known from natural rocky bottoms (Whitehead et al., 1984, 1986a, 1986b; Lythgoe and Lythgoe, 1992). Thus, these species may compete for holes and crevices in rocky outcrops, especially when such spatial resources are limited, as in the case of the south-eastern Mediterranean (Spanier et al., 1988, 1990). The fact that the above 3 species overlap in their depth distribution in the shallow continental shelf (10-50m) (Whitehead et al., 1984, 1986a) may enhance this competition.

$S$. rubrum and E. marginatus may also compete on food resources since they share similar diets, despite the fact that the former is more crepuscular while the latter seems to be more diurnal. Red Squirrelfish feed on crustaceans, polychaetes worms, molluscs and fish (Golani et al., 1983, Ben-Eliyahu et al., 1983) while Dusky Groupers feed on molluscs, crustaceans and fish (Lythgoe and Lythgoe, 1992). We do not know however, to what extent their food resources are limited to justify competition.

Por (1989) refers to a report by Sorbini of Sargocentron $c f$. rubrum from the lower and middle Pliocene stating that this species is known in the Miocene Mediterranean basin. He suggests that it must have survived the Messinian salinity crisis in place. Not surprisingly, remarks Por (1989), this species was among the first species to recolonize the Mediterranean. The present study provides additional evidence for the competitive nature of the Red Squirrelfish.

Seaman (1995) outlined five main purposes of artificial reefs: commercial fishing, recreational fishing, SCUBA diving sites, environmental restoration and management.

In view of the findings of the present study, a sixth purpose of man-made artificial reef can be added, the use of these structures as indicators for long-term ecological changes, at least among bony fishes.

\section{ACKNOWLEDGEMENTS}

Thanks are due to S. Breitstein, Y. Tur-Caspa and G. Shahaf for their invaluable assistance in the underwater censuses. Dr. K. Lavalli is acknowledged for her help in preparing this manuscript and Dr. M. Goren for his constructive comments.

\section{REFERENCES}

Ben-Eliyahu, M. N, D. Golani and A. Ben-Tuvia. - 1983. On predation on polychaetes (Annelids) by the squirrelfish Adioryx ruber (Holocentridae), with a new polychaetes record for the Mediterranean coast of Israel. Tethys 11: 15-19.

Bohnsack, J.A., D.L. Johnson and R.F. Ambrose. - 1991. Ecology of artificial reef habitats and fishes. In: W. Seaman and L. M. Sprague, (eds.), Artificial habitat for marine and freshwater fisheries, pp. 61-107. Academic Press, San Diego.

Bortone, S.A., T. Martin and C.M. Bundrick. - 1994. Factors affecting fish assemblage development on a modular artificial reef in northern Gulf of Mexico estuary. Bull. Mar. Sci. 55: 319-332.

Campbell, A.C. - 1982. The Hamlyn Guide to the flora and fauna of the Mediterranean Sea. Hamlyn, London.

Golani, D., A. Ben-Tuvia and B. Galil. - 1983. Feeding habits of the Suez Canal migrant squirrelfish, Sargocentron rubrum, in the Mediterranean Sea. Israel J. Zool. 32: 194-204.

Golani, D. - 1996. The marine ichthyofauna of the Eastern Levanthistory, inventory and characterization. Israel J. Zool. 42: 1555.

Fredj, G. and C. Maurin . - 1987. Les poissons dans la banque de données MEDIFAUNA. Application a l'étude des caractéris- 
tiques de la fauna ichthyologique Mediterranenne. Cybium 11: 217-215.

Lythgoe, J. and G. Lythgoe. - 1992. Fishes of the sea, the North Atlantic and Mediterranean. MIT Press, Cambridge.

Por, F.D. - 1978. Lessepsian Migration - The influx of Red Sea biota into the Mediterranean by way of the Suez Canal. Springer - Verlag, Berlin.

Por, F.D. - 1989. The legacy of Tethys - an aquatic biogeography of the Levant. Kluwer, Dordrecht.

Russell, B.C.,. F.H. Talbot, G.R.V. Anderson and B. Goldman. 1978. Collection and sampling of reef fishes. In: D.R. Stoddart and R.F Johannes (eds.), Coral reef - research methods, pp. 329-345. UNESCO, Paris.

Santos, M.N., C.C. Monterio and G. Lassérre. - 1997. Finfish attraction and fisheries enhancement on artificial reefs: a review. In: A.C. Jensen (ed), European Artificial Reef Research, Proceedings of the $1^{\text {st }}$ EARRN conference, Ancona. Italy, March 1996, pp. 97-114. Southampton Oceanography Centre, Southampton.

Seaman, W. Jr. - 1995. Artificial habitats for fish. In: Encyclopedia of Environmental Biology, pp. 93-94. Academic Press, New York.

Spanier, E. - 1989. How to increase fisheries yield in low productive marine environment. In: Proceeding of OCEAN ' 89 International Conference. Vol. 1, pp. 297-301. IEEE Publications, Seattle.

Spanier, E. - 1997. Assessment of habitat selection behavior in macroorganisms on artificial reefs. In: A.C. Jensen (ed), European Artificial Reef Research, Proceedings of the $1^{\text {st }}$ EARRN conference, Ancona. Italy, March 1996, pp. 323-336. Southampton Oceanography Centre, Southampton.

Spanier, E., M. Tom and S. Pisanty. - 1985a. Enhancement of fish recruitment by artificial enrichment of man-made reefs in the south-eastern Mediterranean. Bull. Mar. Sci. 37: 356-363.

Spanier, E., M. Tom, S. Pisanty, S. Breitstein, Y. Tur-Caspa and G.
Almog. - 1985b. Development of artificial reefs for commercial species and open sea fish culturing in the south-eastern Mediterranean. In: C.T. Mitchell (ed.), Proceedings of the Joint International Scientific Diving Symposium, pp. 123-135. Academy of Underwater Sciences, La Jolla.

Spanier, E., M. Tom, S. Pisanty and G. Almog. - 1988. Seasonality and shelter selection by the slipper lobster Scyllarides latus in the south-eastern Mediterranean. Mar. Ecol. Prog. Ser. 42: 247-255.

Spanier, E., M. Tom, S. Pisanty and G. Almog-Shtayer. - 1989. The fish assemblage on a coralligenous shallow shelf off the Mediterranean coast of northern Israel. J. Fish Bio. 35: 641649.

Spanier, E., M. Tom, S. Pisanty and G. Almog-Shtayer. - 1990. Artificial reefs in the low productive marine environment of the south-eastern Mediterranean. Mar. Ecol. (P.S.Z.N.I) 11: 61-75.

Spanier, E. and B.S. Galil. - 1991. Lessepsian migration: a continuous biogeographical process. Endeavour 15: 102-106.

Stone, R.B., J.M. McGurrin, L.M. Sprague and W. Seaman. - 1991 Artificial habitat of the world: synopsis and major trends. In: W. Seaman and L.M. Sprague (eds.), Artificial habitat for marine and freshwater fisheries, pp. 31-60. Academic Press, San Diego.

Whitehead, P.J.P., M.-L. Bauchot, J.-C. Hureau, J. Nielsen, and E. Tortunese, (eds.). - 1984. Fishes of the North-Eastern Atlantic and the Mediterranean. Vol. I. Unesco, Paris.

Whitehead, P.J.P., M.-L. Bauchot, J.-C. Hureau, J. Nielsen, and E. Tortunese, (eds.). - 1986a. Fishes of the North-Eastern Atlantic and the Mediterranean. Vol. II. Unesco, Paris.

Whitehead, P.J.P., M.-L. Bauchot, J.-C. Hureau, J. Nielsen, and E. Tortunese, (eds.). -1986b. Fishes of the North - Eastern Atlantic and the Mediterranean. Vol. III. Unesco, Paris.

Scient. ed.: J. McDowell 